\title{
HEMATOLOGICAL CHANGES OF ENDOGENIC INTOXICATION, NON-SPECIFIC REACTIVITY AND INFLAMMATION ACTIVITY INDICES IN HIV-INFECTED PATIENTS
}

DOI: 10.36740/WLek202005127

\author{
Mykola D. Chemych', Dmytro S. Sosnovenko' , Oksana M. Chemych', Oleh B. Berest ${ }^{2}$ \\ 'DEPARTMENT OF INFECTIOUS DISEASES AND EPIDEMIOLOGY, SUMY STATE UNIVERSITY, SUMY, UKRAINE \\ 2DEPARTMENT OF COMPUTER SCIENCE, SUMY STATE UNIVERSITY, SUMY, UKRAINE
}

\begin{abstract}
The aim: To establish changes in hematological parameters of endogenous intoxication, nonspecific reactivity, activity of inflammation in HIV-infected persons, to improve verification of the clinical stage of the disease.

Materials and methods: Anamnestic, clinical, laboratory data. The statistical processing was performed in the Microsoft Office Excel 2010 and IBM SPSS Statistic 23 computer software, variational statistics processing (Student's t-criteria).

Results: 51 HIV-infected were examined (main group) and 44 clinically anamnestic healthy blood donors (comparison group). The study included 46 patients (5 were withdrawn due to failure to meet criteria - severe septic condition).

All patients were divided into three groups: A1 - all patients, 46 persons, men $76.0 \%$, women - 24.0\%; A2 - 11 people with I-III stages of HIV infection, men $72,7 \%$, women - 27,3\%; A3 - 35 HIV infected with stage IV disease, men $76.0 \%$, women $-24.0 \%$.

All patients had an increase in intoxication indices and sex-dependent changes.

Nonspecific reactivity indices in group A1 were above the norm, independent of gender except the index of neutrophils and lymphocyte (NLR). Below the norm is the immunoreactivity index (IR), the lymphocyte-monocyte ratio index (LMR), the lymphocyte index (llymph), the index of allergization (IA).

Indices of nonspecific reactivity of $A 2$ patients exceeded the norm and were independent of sex, with the exception of IR, Ilymph, IA, which were reduced. Non-specific reactivity indices are increased in HIV-infected group A3. Below the norm were IR, LMR, llymph, IA.

Analyzing the activity indexes of inflammation, it became clear that the Krebs index (KI) was increased in all groups of patients; lymphocyte-granulocyte index (ILG) in groups $A 1$ and $A 3$ is less than normal, unlike patients in group $A 2$, where it remained within the normal range. The leukocyte ratio and erythrocyte sedimentation rate (ILESR) in A1 and $\mathrm{A} 3$ have increased rates, unlike in $\mathrm{A} 2$, where the index is smaller.

Conclusions: Men are predominantly HIV positive. The systemic immune response is more pronounced in women. There is a progressive impairment of immunological reactivity, indicating an immunodeficiency of the cell type with a decrease in nonspecific anti-infective protection. Patients with stage IV of HIV infection have moderate and severe inflammatory reactions, impaired reactivity, and are more pronounced in women.
\end{abstract}

KEY WORDS: HIV infection, integrative indicators, disease stages

Wiad Lek. 2020;73(5):983-987

\section{INTRODUCTION}

Blood cells are qualitatively and quantitatively interconnected with various tissues of the human body, having the ability to disrupt the constancy of the indicators and the normal ratio to each other, reflecting all physiological or pathophysiological processes of inflammatory, allergic, autoimmune or oncological genes $[1,2]$.

The pathogenesis of HIV infection is of great importance for the selectivity of the immune system virus, the main purpose of which is to protect the body from pathogenic infectious agents, and to ensure the equilibrium of the pathogenic microflora of the body [3].

Research of the development mechanism and pathological processes severity in various organs and tissues of the body using integrative hematologic parameters is a relevant topic of the current research for HIV.

\section{THE AIM}

To establish changes in indicators of endogenous intoxication, nonspecific reactivity, activity of inflammation in $\mathrm{HIV}$-infected at different stages of the disease and improve verification of the clinical stage of the disease.

\section{MATERIALS AND METHODS}

51 HIV-infected were examined. Patients were mostly hospitalized (80\%).

The criteria of involvement in the study was clearly confirmed and established the diagnosis of HIV. Exclusion criteria were: severe septic condition, autoimmune diseases. Five patients were removed from the study for non-compliance with the criteria.

Among the patients enrolled in the study were 35 men and 11 women, aged $(40.75 \pm 1.21)$ years. Of these, 3 people 
with stage I HIV- infection, 2 with - II, 6 with - III and 35 with IV. The comparison group consisted of 44 clinically anamnestic healthy blood donors aged $(37.95 \pm 1.72)$ years.

It was performed: collecting of epidemiological, clinical and anamnestic data, clinical and laboratory studies. Using our developed Android mobile application [4], it was calculated integrative indicators of endogenous intoxication and immunoreactivity: leucocyte intoxication index (LII), hematological index of intoxication (HII), index of leucocytes shift (ISL), Krebs index (KI), immunoreactivity index (IR), lymphocyte-granulocyte index (ILG), neutrophil-lymphocyte ratio (NLR), lymphocyte-monocyte ratio (LMR), neutrophil reactive response (NRR), index of leukocyte and ESR ratio (ILESR), lymphocyte index $\left(\mathrm{I}_{\text {lymph }}\right)$, eosinophils-lymphocyte ratio (ELR), index of allergization (IA), nuclear index (NI), index of intoxication severity (IIS) $[5,6]$.

The statistical processing was performed in the Microsoft Office Excel 2010 and IBM SPSS Statistic 23 computer software. Data were checked for group distribution normality using the Shapiro-Wilk statistics. In the groups of patients we used parametric methods because the obtained data conform the normal distribution - Student's t-test was used to analyze the quantitative data.

Present information about study design, applied methods and search of conflicts of interest when conceptualizing the data and before writing a final text of original article. Keeping a non-interventional nature of the presented work the appropriate anonymity and personal data processing were ethically verified according to the local hospital and the All-Ukrainian rules and orders. Basically, he Declaration of Helsinki (6th, rev., 2008, Seol) and the Universal Declaration on Bioethics and Human Rights (2006) were a key documentation considering ethical decision making and conceptualization for the article's scientific content.

\section{RESULTS}

All patients were divided into three groups: the first group (A1) included all HIV-infected persons - 46 persons, men were $76.0 \%$, women $-24.0 \%$, the average age was $(40.75$ \pm 1.21 ) years ; in the second (A2) group - 11 people with I - III stages of HIV infection, men $72,7 \%$, women - $27,3 \%$, aged $(44,9 \pm 1,21)$ years; in the third (A3) - 35 persons with stage IV disease only, men were $76.0 \%$, women $-24.0 \%$, age $(39.6 \pm 1.31)$ years.

In group A1, there was an increase in the index of intoxication compared to the norm - LII (by 2.0 times), ISL (by 1.7), HII (by 4.9), IIS (by 19.0), NRR (by 2.5 ). The dependence of indicators of HII, IIS, NRR on sex was found, in women they were higher than in men (respectively - in $2.2 ; 2.1 ; 1.2$ times) $(\mathrm{p}<0.05-0.001)$ (Table 1$)$.

Patients in the A2 group had similar changes, except for the IIS, which was above the norm by 25.0 times, and depending on the sex, the indicator was higher in women than in men by 2.7 times, and more than in the HIV-infected A1 groups by 1.3 times ( $\mathrm{p}<0.05-0.001$ ). Although NRR increased 1.4-fold and was sex-dependent (2.7-fold higher in women than in men), it was 1.7 -fold lower than in the A1 group ( $\mathrm{p}<0.05-0.001)$.

Indicators of group A3 did not differ significantly from each other, did not depend on sex, except for HII and IIS, which increased by 5.0 and 17.8 times, respectively, depending on gender - exceeded for men, respectively - by 2.1 and 1.9 times $(\mathrm{p}<0.05-0.001)$.

Non-specific reactivity indices in group A1 were changed as follows: NLR, ELR, NI were above the norm, respectively - by 1.2, 1.2, 3.5 times ( $\mathrm{p}<0.05-0.001)$. The changes did not depend on sex, except NLR in women which was higher by 1.6 than in men $(p<0.05-0.001)$. Other indicators - IR, LMR, Ilymph, IA were below the norm, 1.1, 1.3, 1.4, 1.2 times $(\mathrm{p}<0.05-0.001)$, respectively, and did not depend on gender.

A2 patients indices of nonspecific reactivity: IR, LMR, ELR, NI, exceeded the norm by 1.1, 1.3, 1.2, 1.5 times respectively, and did not depend on sex, with the exception of IR, which was higher in men by 1.2 times more than women $(\mathrm{p}<0.05-0.001)$. Ilymph - below the norm by 1.1 times, regardless of gender $(p<0.05-0.001)$. Normal level were LMR and IA. LMR and IA in women is 1.3 times lower than in men.

The non-specific reactivity index - NLR, ELR, and NI in HIV-infected group A3 increased by 1.2, 1.2, and 4.1 times, respectively $(\mathrm{p}<0.05-0.001)$. Were increased NLR $(1.9$ times), ELR (1.2 times) in women was more pronounced than in men $(p<0.05-0.001)$. Below the norm, regardless of gender, in this group were IR (1.3), LMR (1.4), Ilymph (1.4), IA (1.3 times) ( $\mathrm{p}<0.05-0.001)$.

Analyzing the indices of nonspecific reactivity it is established: NLR, Ilymph, ELR indices have no significant intergroup differences; IR, LMR, IA - have insignificant differences in groups A1 and A3. Comparing the data with the indicators of the $\mathrm{A} 2$ group, it is proved that the IR index is 1.3 and 1.4 times higher than in the $\mathrm{A} 1$ and $\mathrm{A} 3$ groups $(\mathrm{p}<0.05-0.001) ; \mathrm{LMR}$ and IA within the normal range, but also more than 1.3 (A1), 1.4 (A3) times and 2.3, 2.7 times, respectively $(\mathrm{p}<0.05-0.001)$.

The analysis of inflammatory activity indices showed an increase in patients with A1 - KI, ILESR (2.0 - 4.8 times) and gender dependence compared to normal, in women they are higher than in men $(1.3-1.8$ times) $(\mathrm{p}<0.05-$ $0.001)$. ILG is 1.2 times less than normal $(\mathrm{p}<0.05-0.001)$ and independent of sex.

More pronounced changes in KI and ILESR in the A2 group were higher than normal by 1.8 and 3.8 times, respectively, in women more than in men by 1.7 and 2.1 times $(\mathrm{p}<0.05-0.001)$, respectively. ILG was not different from the norm, but was greater in men by 1.2 times ( $\mathrm{p}<0.05-0.001)$.

In the $\mathrm{A} 3$ group, KI and ILESR significantly exceeded the norm -2.1 and 5.1 times $(\mathrm{p}<0.05-0.001)$, respectively. Gender dependence on ILESR, where the rates for women are 1.7 times higher compared with men. ILG was less than 1.2 -fold and non-sex-dependent $(\mathrm{p}<0.05-0.001)$. Analyzing changes in KI, ILG, ILESR depending on the group of patients A1, A2, A3, it is found out: $\mathrm{KI}$ is increased in all patients, and has slight deviations in the groups; ILG in A1 
Table I. Changes integrative indicators of endogenic intoxication in hiv-infected.

\begin{tabular}{|c|c|c|c|c|c|c|c|c|c|c|}
\hline \multirow{3}{*}{ Index } & \multicolumn{10}{|c|}{ Group, $\mathbf{n}$} \\
\hline & \multirow{2}{*}{ comparison } & \multicolumn{3}{|c|}{$A 1, n=46$} & \multicolumn{3}{|c|}{ A2, $n=11$} & \multicolumn{3}{|c|}{$A 3, n=35$} \\
\hline & & all & men & women & all & men & women & all & men & women \\
\hline 1 & 2 & 3 & 4 & 5 & 6 & 7 & 8 & 9 & 10 & 11 \\
\hline \multicolumn{11}{|c|}{ Index endogenic intoxication } \\
\hline LII & $\begin{array}{c}0,70 \pm \\
0,07\end{array}$ & $\begin{array}{c}1.44 \pm 0.2 \\
a\end{array}$ & $\begin{array}{c}1.35 \pm 0.19 \\
a\end{array}$ & $\begin{array}{c}1.72 \pm 0.5 \\
a\end{array}$ & $\begin{array}{c}1.43 \pm 0.35 \\
a\end{array}$ & $\begin{array}{c}1.25 \pm 0.26 \\
a\end{array}$ & $\begin{array}{c}1.9 \pm 0.55 \\
a\end{array}$ & $\begin{array}{c}1.44 \pm 0.22 \\
a\end{array}$ & $\begin{array}{c}1.38 \pm 0.21 \\
a\end{array}$ & $\begin{array}{c}1.66 \pm 0.41 \\
\mathrm{a}\end{array}$ \\
\hline ISL & $\begin{array}{c}1,62 \pm \\
0,10\end{array}$ & $\begin{array}{c}2.77 \pm 0.3 \\
a\end{array}$ & $\begin{array}{c}2.6 \pm 0.28 \\
a\end{array}$ & $\begin{array}{c}3.3 \pm 0.8 \\
\mathrm{a}\end{array}$ & $\begin{array}{c}2.71 \pm 0.53 \\
a\end{array}$ & $\begin{array}{c}2.34 \pm 0.34 \\
a\end{array}$ & $\begin{array}{c}3.65 \pm 1.0 \\
a\end{array}$ & $\begin{array}{c}2.79 \pm 034 \\
a\end{array}$ & $\begin{array}{c}2.68 \pm 0.33 \\
a\end{array}$ & $\begin{array}{c}3.17 \pm 0.72 \\
\mathrm{a}\end{array}$ \\
\hline $\mathrm{HII}$ & $\begin{array}{c}0,64 \pm \\
0,06\end{array}$ & $\begin{array}{c}3.15 \pm 0.6 \\
a\end{array}$ & $\begin{array}{c}2.45 \pm 0.45 \\
a\end{array}$ & $\begin{array}{c}5.37 \pm 1.96 \\
a\end{array}$ & $\begin{array}{c}2.87 \pm 0.98 \\
a\end{array}$ & $\begin{array}{c}2.1 \pm 0.72 \\
a\end{array}$ & $\begin{array}{c}5.14 \pm 2.1 \\
a\end{array}$ & $\begin{array}{c}3.2 \pm 0.68 \\
a\end{array}$ & $\begin{array}{c}2.56 \pm 0.5 \\
a\end{array}$ & $\begin{array}{c}5.46 \pm 2.09 \\
\mathrm{a}\end{array}$ \\
\hline IIS & $\begin{array}{c}0,16 \pm \\
0,02 \\
\end{array}$ & $\begin{array}{c}3.12 \pm 0.74 \\
\mathrm{a} \\
\end{array}$ & $\begin{array}{c}2.46 \pm 0.58 \\
a\end{array}$ & $\begin{array}{c}5.24 \pm 2.46 \\
a\end{array}$ & $\begin{array}{c}4.01 \pm 1.9 \\
a\end{array}$ & $\begin{array}{c}2.72 \pm 1.2 \\
a\end{array}$ & $\begin{array}{c}7.44 \pm 3.3 \\
a\end{array}$ & $\begin{array}{c}2.85 \pm 0.74 \\
a\end{array}$ & $\begin{array}{c}2.38 \pm 0.57 \\
a\end{array}$ & $\begin{array}{c}4.41 \pm 2.1 \\
a\end{array}$ \\
\hline NRR & $\begin{array}{c}12,75 \pm \\
1,82 \\
\end{array}$ & $\begin{array}{c}32.08 \pm 4.49 \\
a, c\end{array}$ & $\begin{array}{c}30.37 \pm 4.93 \\
a, c \\
\end{array}$ & $\begin{array}{c}37.53 \pm 10.6 \\
\mathrm{a} \\
\end{array}$ & $\begin{array}{c}18.63 \pm 2.2 \\
a, b \\
\end{array}$ & $\begin{array}{c}12.47 \pm 1.58 \\
a, b\end{array}$ & $\begin{array}{c}35.05 \pm 10.9 \\
a \\
\end{array}$ & $\begin{array}{c}36.31 \pm 5.23 \\
a, c\end{array}$ & $\begin{array}{c}35.68 \pm 5.9 \\
a, c\end{array}$ & $\begin{array}{c}38.46 \pm 9.03 \\
\mathrm{a}\end{array}$ \\
\hline \multicolumn{11}{|c|}{ Index non-specific reactivity } \\
\hline IR & $\begin{array}{c}4,65 \pm \\
0,36\end{array}$ & $\begin{array}{c}3.98 \pm 0.39 \\
\mathrm{a}\end{array}$ & $\begin{array}{c}3.98 \pm 0.4 \\
a, c\end{array}$ & $\begin{array}{c}3.96 \pm 0.68 \\
a \\
\end{array}$ & $\begin{array}{c}5.23 \pm 0.8 \\
a\end{array}$ & $\begin{array}{c}5.74 \pm 0.4 \\
a, b\end{array}$ & $\begin{array}{c}3.89 \pm 0.42 \\
a\end{array}$ & $\begin{array}{c}3.58 \pm 0.39 \\
a\end{array}$ & $\begin{array}{c}3.46 \pm 0.43 \\
a, c\end{array}$ & $\begin{array}{c}3.98 \pm 0.63 \\
a\end{array}$ \\
\hline NLR & $\begin{array}{c}8,88 \pm \\
0,91 \\
\end{array}$ & $\begin{array}{c}10.86 \pm 1.51 \\
a\end{array}$ & $\begin{array}{c}9.39 \pm 0.58 \\
a \\
\end{array}$ & $\begin{array}{c}15.53 \pm 1.43 \\
\mathrm{a}\end{array}$ & $\begin{array}{c}11.34 \pm 0.82 \\
a\end{array}$ & $\begin{array}{c}11.01 \pm 0.74 \\
\mathrm{a}\end{array}$ & $\begin{array}{c}12.24 \pm 1.24 \\
\mathrm{a}\end{array}$ & $\begin{array}{c}10.71 \pm 1.75 \\
a\end{array}$ & $\begin{array}{c}8.92 \pm 0.46 \\
a, c\end{array}$ & $\begin{array}{c}16.76 \pm 3.8 \\
\mathrm{a} \\
\end{array}$ \\
\hline LMR & $\begin{array}{c}4,77 \pm \\
0,45\end{array}$ & $\begin{array}{c}3.64 \pm 0.27 \\
a \\
\end{array}$ & $\begin{array}{c}3.65 \pm 0.32 \\
a, c\end{array}$ & $\begin{array}{c}3.62 \pm 0.34 \\
a \\
\end{array}$ & $\begin{array}{c}4.73 \pm 0.6 \\
a\end{array}$ & $\begin{array}{c}5.15 \pm 0.67 \\
a, b\end{array}$ & $\begin{array}{c}3.61 \pm 0.42 \\
a \\
\end{array}$ & $\begin{array}{c}3.3 \pm 0,41 \\
a\end{array}$ & $\begin{array}{c}3.21 \pm 0.42 \\
a, c\end{array}$ & $\begin{array}{c}3.62 \pm 0.35 \\
\mathrm{a}\end{array}$ \\
\hline Ilymph & $\begin{array}{c}0,59 \pm \\
0,04 \\
\end{array}$ & $\begin{array}{c}0.43 \pm 0.03 \\
a \\
\end{array}$ & $\begin{array}{c}0.43 \pm 0.05 \\
a \\
\end{array}$ & $\begin{array}{c}0.44 \pm 0.06 \\
a \\
\end{array}$ & $\begin{array}{c}0.51 \pm 0.09 \\
a \\
\end{array}$ & $\begin{array}{c}0.54 \pm 0.097 \\
a \\
\end{array}$ & $\begin{array}{c}0.42 \pm 0.06 \\
a \\
\end{array}$ & $\begin{array}{c}0.41 \pm 0.05 \\
a \\
\end{array}$ & $\begin{array}{c}0.4 \pm 0.05 \\
a \\
\end{array}$ & $\begin{array}{c}0.44 \pm 0.06 \\
\mathrm{a} \\
\end{array}$ \\
\hline ELR & $\begin{array}{l}0,08 \pm \\
0,009\end{array}$ & $\begin{array}{c}0.1 \pm 0.004 \\
a \\
\end{array}$ & $\begin{array}{c}0.09 \pm 0.006 \\
a \\
\end{array}$ & $\begin{array}{c}0.11 \pm 0.01 \\
a\end{array}$ & $\begin{array}{c}0.1 \pm 0.004 \\
a \\
\end{array}$ & $\begin{array}{c}0.1 \pm 0.008 \\
a \\
\end{array}$ & $\begin{array}{c}0.09 \pm 0.01 \\
a \\
\end{array}$ & $\begin{array}{c}0.1 \pm 0.004 \\
a \\
\end{array}$ & $\begin{array}{c}0.09 \pm 0.007 \\
a \\
\end{array}$ & $\begin{array}{c}0.11 \pm 0.01 \\
\mathrm{a}\end{array}$ \\
\hline \multicolumn{11}{|c|}{ Continuation of table I } \\
\hline 1 & 2 & 3 & 4 & 5 & 6 & 7 & 8 & 9 & 10 & 11 \\
\hline IA & $\begin{array}{c}1,05 \pm \\
0,07\end{array}$ & $\begin{array}{c}0.83 \pm 0.064 \\
a \\
\end{array}$ & $\begin{array}{c}0.83 \pm 0.08 \\
a\end{array}$ & $\begin{array}{c}0.84 \pm 0.07 \\
a \\
\end{array}$ & $\begin{array}{c}0.99 \pm 0.05 \\
a \\
\end{array}$ & $\begin{array}{c}1.08 \pm 0.11 \\
a\end{array}$ & $\begin{array}{c}0.77 \pm 0.12 \\
a\end{array}$ & $\begin{array}{c}0.78 \pm 0.08 \\
a, c\end{array}$ & $\begin{array}{c}0.75 \pm 0.08 \\
a, c\end{array}$ & $\begin{array}{c}0.87 \pm 0.05 \\
\mathrm{a} \\
\end{array}$ \\
\hline $\mathrm{NI}$ & $\begin{array}{c}0,06 \pm \\
0,01 \\
\end{array}$ & $\begin{array}{c}0.21 \pm 0.04 \\
a, c\end{array}$ & $\begin{array}{c}0.21 \pm 0.04 \\
a, c\end{array}$ & $\begin{array}{c}0.21 \pm 0.05 \\
a, c\end{array}$ & $\begin{array}{c}0.09 \pm 0.01 \\
a, b\end{array}$ & $\begin{array}{c}0.09 \pm 0.01 \\
a, b\end{array}$ & $\begin{array}{c}0.1 \pm 0.012 \\
a, b\end{array}$ & $\begin{array}{c}0.25 \pm 0.04 \\
a, c\end{array}$ & $\begin{array}{c}0.24 \pm 0.06 \\
a, c\end{array}$ & $\begin{array}{c}0.25 \pm 0.06 \\
a, c\end{array}$ \\
\hline \multicolumn{11}{|c|}{ Index inflammation activity } \\
\hline $\mathrm{KI}$ & $\begin{array}{c}2,02 \pm \\
0,94\end{array}$ & $\begin{array}{c}4.13 \pm 0.26 \\
a\end{array}$ & $\begin{array}{c}3.84 \pm 0.46 \\
a\end{array}$ & $\begin{array}{c}5.07 \pm 1.1 \\
a\end{array}$ & $\begin{array}{c}3.67 \pm 0.38 \\
a\end{array}$ & $3.05 \pm 0.28$ & $\begin{array}{c}5.35 \pm 1.3 \\
a\end{array}$ & $\begin{array}{c}4.28 \pm 0.63 \\
a\end{array}$ & $\begin{array}{c}4.08 \pm 0.42 \\
a, c\end{array}$ & $\begin{array}{c}4.96 \pm 1.1 \\
a\end{array}$ \\
\hline ILG & $\begin{array}{c}4,85 \pm \\
0,29 \\
\end{array}$ & $\begin{array}{c}4.1 \pm 0.24 \\
a \\
\end{array}$ & $\begin{array}{c}4.14 \pm 0.2 \\
\mathrm{a}\end{array}$ & $\begin{array}{c}4.0 \pm 0.3 \\
a \\
\end{array}$ & $\begin{array}{c}4.75 \pm 0.33 \\
a \\
\end{array}$ & $\begin{array}{c}5.01 \pm 0.58 \\
a \\
\end{array}$ & $\begin{array}{c}4.05 \pm 0.27 \\
a \\
\end{array}$ & $\begin{array}{c}3.9 \pm 0.37 \\
a \\
\end{array}$ & $\begin{array}{c}3.88 \pm 0.38 \\
a \\
\end{array}$ & $\begin{array}{c}3.98 \pm 0.32 \\
\mathrm{a} \\
\end{array}$ \\
\hline ILESR & $\begin{array}{c}1,33 \pm \\
0,20\end{array}$ & $\begin{array}{c}6.46 \pm 0.7 \\
a\end{array}$ & $\begin{array}{c}5.42 \pm 0.75 \\
a\end{array}$ & $\begin{array}{c}9.77 \pm 1.22 \\
a\end{array}$ & $\begin{array}{c}5.09 \pm 1.15 \\
a\end{array}$ & $\begin{array}{c}3.87 \pm 1.14 \\
a\end{array}$ & $\begin{array}{c}8.37 \pm 1.67 \\
a\end{array}$ & $\begin{array}{c}6.89 \pm 0.84 \\
a\end{array}$ & $\begin{array}{c}5.88 \pm 0.9 \\
a\end{array}$ & $\begin{array}{c}10.3 \pm 1.66 \\
a\end{array}$ \\
\hline
\end{tabular}

Annotations. Significant difference in metrics ( $p<0,05-0,001$, we used Student's t-criteria): $a$ - about the comparison group; $b$ - about the group A1; c - about the group A2.

and $\mathrm{A} 3$ groups is less than normal, unlike patients in A2 group, where it remained within the normal range, but by 1.1 and 1.2 times more that in $\mathrm{A} 1$ and $\mathrm{A} 3(\mathrm{p}<0.05-0.001)$. ILESR in the A1 and A3 groups have similar increased rates, unlike the $\mathrm{A} 2$ group, where the index is 1.3 and 1.4 times lower, respectively $(\mathrm{p}<0.05-0.001)$.

\section{DISCUSSION}

The obtained changes in patients of group A1 indicate an increase in the level of endogenous intoxication and activation of tissue breakdown processes, marked activity of the inflammatory process and impaired immunological reactivity. There is a clear systemic response to inflammatory processes in the body of patients, the likely development of decompensated endogenous intoxication [7]. However, the fact that comparing intoxication indices in different sex subgroups, where indicators are higher in women than in men, we can say that the prevalence of pathological phenomena in women.

Comparison of the obtained data indicates the presence of signs of acute inflammatory process [8,9], which is more active in persons of group A2 than in A1, we can also note that signs of acute inflammatory process are more active 
in women of group A2. It should be noted that signs of an acute inflammatory process are more pronounced in men from group A2 compared to group A1. There is a pronounced systemic response to inflammatory processes in the body of patients in both groups, and the degree of endogenous intoxication and activation of tissue decay processes in the subjects does not differ. Immune reactivity is impaired, which has a more pronounced development in A2 group women. The development of decompensated endogenous intoxication is less intense in the A2 group and more active in women [10].

The severity of the acute inflammatory process is less intense in people in group A3 than others. The activity of increasing the level of endogenous intoxication and activation of tissue decay processes in the subjects of this group is not different.

Immune reactivity disorders of the same intensity are observed in all groups.

Decompensated endogenous intoxication is more pronounced in HIV-infected A3 groups than in A1 and A2, more pronounced in women.

All HIV-infected people have a shift of the leukocyte formula to the left, activation of a non-specific inflammatory process, development of autoimmune processes, predominance of slow-type reactions over immediate-type hypersensitivity. Also, an inflammatory response of mild severity, changes in white shoots of blood, and antigenic and cytokine stimulation have been established - this testifies to the intoxication of patients and the loss of the ability of neutrophils to eliminate antigens, which is explained by the increase in young forms of rod-shaped neutrophils. The described pathological phenomena are more clearly manifested in women. We observe an active adaptive response of white blood and the immunodeficiency state of the cell type, a decrease in nonspecific anti-infection protection of the examined [11,12]. It can be argued that A2 patients have a tendency to develop a septic condition [13-15], with men at greater risk of developing. People in group A3 were characterized by the development of intoxication, an inflammatory reaction that was more intense in women. Shifting the leukocyte formula to the left, the activation of nonspecific inflammatory processes with the development of autoimmune phenomena have a more active course in women in this group. Patients of this group are characterized by the development of intoxication, an inflammatory reaction of mild severity; development of endogenous intoxication and impaired immunological reactivity due to auto-intoxication of the body in the destruction of own cells under the influence of bacterial toxins [12-15].

\section{CONCLUSIONS}

1. Middle-aged men are predominantly HIV positive. The systemic immune response to acute inflammatory processes is present in all examined patients, more pronounced in women, higher in patients with I, II, and III stages of the disease, which is confirmed by an increase in indicators of LII, ISL, HII, IIS, NRR.

2. In all study groups there is a progressive $(\mathrm{A} 1 \leq \mathrm{A} 2 \leq \mathrm{A} 3)$ impaired immunological reactivity, which is accompa- nied by significant fluctuations and more pronounced in women, towards an increase (ELR, NLR, NI), or a decrease (IA, Ilymph), indicating immunodeficiency cell type with reduction of nonspecific anti-infective protection, shift of leukocyte formula to the left, development of autoimmune processes, predominance of slow-type reactions over immediate-type hypersensitivity, leading to sensitization of the body, triggering of allergic mechanisms of background intoxication.

3. In patients with stage IV HIV infection, there are processes of moderate and severe inflammatory reactions, impaired reactivity due to auto-intoxication of the body in the destruction of own cells under the influence of bacterial toxins, more pronounced in women, which is confirmed by an increase of KI and ILESR with decreasing ILG.

\section{REFERENCES}

1. Harbol A.W., Liesveld J.L., Simpson-Haidaris, et al.. Mechanisms of cytopenia in human immunodeficiency virus infection. Blood Rev. 1994; 8: 241-251. D01: 10.1016/0268-960x (94) 90112-0

2. Zaza M. Ndhlovu, Samuel W. Kazer, Thandeka Nkosi, et al. Augmentation of HIV-specific T cell function by immediate treatment of hyperacute HIV-1 infection. Science Translational Medicine. 2019; 11(493): 1-2. D01: 10.1126/scitransImed.aau0528

3. Shacklett Barbara L., Ferre April L., Kiniry Brenna E. Tissue issues mucosal T-cell responses in HIV-I infection. Current Opinion in HIV and AIDS. 2019; 14(2): 100-107. DOI: 10.1097/COH.0000000000000530

4. Tetyana Zhylenko, Iryna Shuda, Oksana Chemych, et al. Mobile Application to Determine the Severity of Salmonellosis Disease. International Conference on ICT in Education, Research and Industrial Applications. Integration, Harmonization and Knowledge Transfer. 2018; I(2105): 461-464.

5. Mofenson L.M., Harris D.R., Moye J., et al. Alternatives to HIV-1 RNA concentration and CD4 count to predict mortality in HIV-1-infected children in resource-poor settings. Lancet. 2003; 362: 1625-1627. DOl: 10.1016 / S0140-6736 (03) 14825-8

6. Mohylenets 0 . I. Intehralni hematolohichni pokaznyky yak predyktory dotsilnosti zastosuvannia antybakterialnoi terapii u khvorykh na hostri respiratorni infektsii [Integral hematologic indices as predictors of feasibility of antibacterial therapy in patients with acute respiratory infections]. Science Rise. Medical science. 2015; 10(3):16-19. (UA)

7. Veha A. R., Beklemishcheva A. 0. Aspekty rannoi klinichnoi diahnostyky VIL-infektsii [Aspects of early clinical diagnosis of HIV infection]. Infektsiini khvoroby v praktytsi likaria-internista: suchasni aspekty. Infectious diseases in medical practice internist: modern aspects. 2016; 1:30-32. (UA)

8. Xu Yin Ollerton, Matthew T., Connick Elizabeth. Follicular T-cell subsets in HIV infection recent advances in pathogenesis research. Current Opinion in HIV and AIDS. 2019; 14 (2): 71-76. D0I: 10.1097/ COH.0000000000000525

9. Boulougoura Afroditi; Sereti Irini. HIV infection and immune activation the role of coinfections. Current Opinion in HIV and AIDS. 2016; 11 (2): 191-200. DOI: 10.1097/COH.0000000000000241

10. Siberry G.K., Patel K., Pinto J.A. Elevated aspartate aminotransferaseto-platelet ratio index in perinatally HIV-infected children in the United States. International Journal of Infectious Diseases. 2011; 15 (12): 808-811. DOI: 10.1097/INF.0000000000000348 
11. Arthos J., Cicala C., Nawaz F., et al. The Role of Integrin a4ß37 in HIV Pathogenesis and Treatment. Curr HIV/AIDS Rep. 2018;15(2):127-135. DOI: 10.1007/s11904-018-0382-3.

12. Chemych M. D., Andreichyn M. A., Zakhliebaieva V. V. Intehratyvni pokaznyky endohennoi intoksykatsii ta hematolohichni zminy pry shyhelozi [Integrative indicators of endogenous intoxication and hematological changes in shigellosis] Infektsiini khvoroby. Infectious diseases. 2009; 2: 42-47 (UA)

13. Hogg R.S., Yip B., Chan K.J., et al. Rates of disease progression by baseline CD4 cell count and viral load after initiating triple-drug therapy. Jama. 2001, Nov 28; 286 (20): 2568-77. D0I: 10,1001/ jama.286.20.2568

14. Anastos K., Kalish L.A., Hessol N., et al. The relative value of CD4 cell count and quantitative HIV-1 RNA in predicting survival in HIV-1-infected women: results of the women's interagency HIV study. AIDS. 1999; 13:1717-1726. D0I: 10,1097/00002030-19990910000016

15. Ostrovska L.Y., Moshel T. M., Ivanytskyi I.O. Analiz pokaznykiv hemohram u patsiientiv iz zapalnymy i zapalno-dystrofichnymy zminamy tkanyn parodonta [Analysis of hemograms in patients with inflammatory and inflammatory-dystrophic periodontal tissue changes]. Visnyk problem biolohii i medytsyny. Bulletin of problems of biology and medicine. 2016; 1,1 (126): 360-361. (UA)
The work was performed within the framework of: research work of the Department of Infectious Diseases with Epidemiology of Sumy State University (SSU) "Common Infectious Diseases of the Northern Region of Ukraine: Modern Approaches to Diagnosis and Treatment" (state registration number 0117U003216) (deadline: 2017-2022).

\section{ORCID and contributionship:}

Mykola D. Chemych - 0000-0002-7085-5448 A,B,C,D,E,F

Dmytro S. Sosnovenko - ${ }^{A, B, C, D}$

Oksana M. Chemych - 0000-0003-1332-2175 A,B,C,D,F

Oleh B. Berest - 0000-0003-0183-9871 A,B,C,F

\section{Conflict of interest:}

The Authors declare no conflict of interest

\section{CORRESPONDING AUTHOR Oksana M. Chemych}

2, Rymskogo-Korsakova st., Sumy, Ukraine

tel: +380664764966

e-mail: chemychoksana@gmail.com

Received: 29.01 .2020

Accepted: 30.03 .2020

A - Work concept and design, B - Data collection and analysis, C - Responsibility for statistical analysis,

D-Writing the article, $\mathbf{E}$-Critical review, $\mathbf{F}$ - Final approval of the article 